\title{
HAKIKAT MANUSIA SEBAGAI PENDIDIK DALAM PERSPEKTIF FILSAFAT PENDIDIKAN ISLAM
}

\author{
Oleh : \\ Sulaiman \\ IAI Al - Falah As-sunniyyah Kencong \\ sulaiman mk@ymail.com
}

\begin{abstract}
ABTRACT
Humans become one of the main topics of discussion in education, because education is only intended for humans. Even if there is a training process carried out for certain animals, it is not called education. Because basically animals can not be educated, but only just dressed trained, only limited to the practice of doing something static, without any development of the results of the training that has been done.[1] When animals are unable to develop in their experiences, they are different from humans. Humans with all their abilities, absolutely need an education to develop the ability to lead to a better direction of change.
\end{abstract}

Keywords: Human Rights, Educator, Islamic Education

\begin{abstract}
ABSTRAK
Manusia menjadi salah satu topik bahasan utama dalam pendidikan, karena pendidikan hanya ditujukan untuk manusia. Jikapun ada proses pelatihan yang dilakukan untuk binatang tertentu maka itu bukanlah disebut sebagai pendidikan. Karena pada dasarnya binatang tidak dapat dididik, melainkan hanya sekedar dilatih secara dressur saja, hanya sebatas latihan untuk mengerjakan sesuatu yang statis, tanpa adanya perkembangan dari hasil latihan yang telah dilakukan. ${ }^{1}$ Ketika binatang tidak mampu mengadakan pengembangan dalam pengalaman yang dialaminya, maka berbeda dengan manusia. Manusia dengan segenap kemampuan yang dimilikinya, mutlak membutuhkan suatu pendidikan untuk mengembangkan kemampuan menuju kepada arah perubahan yang lebih baik.
\end{abstract}

Kata Kunci: Hakikat Manusia, Pendidik, Pendidikan Islam

\section{PENDAHULUAN}

Pendidikan merupakan proses pengembangan potensi manusia, maka dari itu proses pendidikan harus berjalan sesuai perkembangan manusia dan memposisikannya sebagai subyek didik seutuhnya. Dalam dunia pendidikan, pendidik merupakan faktor penting dan utama, karena pendidik adalah orang yang bertanggungjawab terhadap perkembangan jasmani dan rohani peserta didik, terutama di sekolah atau madrasah, untuk mencapai kedewasaan peserta

\footnotetext{
${ }^{1}$ Nur Uhbiyati, Ilmu Pendidikan Islam (Bandung: CV. Pustaka Setia, 2005), 86 Vol.DI. No.Z. April 2019 


\section{Sulaiman}

didik sehingga ia menjadi manusia yang paripurna dan mengetahui tugas-tugasnya sebagai manusia yakni hamba Allah ('abd) dan khalifah fi al-ardh.

Di sini dapat dipahami bahwa pendidik merupakan posisi sentral dalam dunia pendidikan tanpa mengabaikan unsur-unsur lain dalam pendidikan, berarti di pundak pendidiklah perkembangan peserta didik dilanjutkan secara continou, maka pendidik semestinya mengetahui makna pendidikan sejati agar peserta didik dapat berkembang dengan sempurna untuk mendapat kebahagian hidup dunia dan akhirat.

Beranjak dari ini, sepatutnya pendidik menyadari terhadap hakekat tugas yang diemban untuk mencerdaskan dan menyucikan hati serta perilaku peserta didik. Tugas yang mulia tersebut apabila dilakukan dengan baik akan memperoleh kebahagiaan dalam diri seorang pendidik.

\section{HAKIKAT MANUSIA DALAM PANDANGAN FILSAFAT}

Satu-satunya makhluk yang senantiasa membahas dan menjadikan dirinya sebagai topik besar dalam bidang kajian setiap pembahasannya adalah manusia. Sehingga manusia menjadi subyek sekaligus obyek pada setiap pokok pembahasan keilmuan tertentu. Dalam kajian filsafat terdapat beberapa pendapat mengenai hakekat manusia, sebagaimana dijelaskan berikut.

Spiritualisme (suatu aliran filsafat yang mementingkan keruhanian, lawan dari materialisme) mengemukakan bahwa semua yang ada di alam ini terdiri dari ruh, sukma, jiwa yang terbentuk dan tidak menempati ruang. Jiwa mempunyai kekuatan dan dapat melakukan tanggapan atau sesuatu yang bukan berasal dari dari tangkapan pancaindra, yang datang secara tiba-tiba berbentuk gambaran melalui alam metafisis di luar jangkauan rasio dan yang bersifat material. ${ }^{2}$ Jadi, pengetahuan manusia berasal dari angan-angan yang murni dan alami pada alam metafisis. Hal ini menunjukkan bahwa walaupun tanpa adanya sebuah tindakan konkret praktik pendidikan manusia mampu memperoleh pegetahuan.

Sedangkan aliran idealisme yang dipelopori oleh Plato (427-374 SM) 3 murid Socrates berpendapat bahwa yang nyata hanyalah idea, idea selalu tetap, tidak mengalami perubahan dan pergeseran. Oleh karena itu alam merupakan gambaran dari idea karena posisinya tidak menetap, termasuk manusia secara jasadiah. Keberadaan manusia diakui karena adanya idea yang dimunculkannya dalam alam metafisiknya. Menurut aliran ini sumber pengetahuan

\footnotetext{
2 Jalaluddin dan Abdullah Idi, Filsafat Pendidikan (Jogjakarta: Ar-Ruzz media, 2009), 63

${ }^{3}$ Jalaluddin, Filsafat.. 64

Jurnal Auladuna | 92

Vol.DI. No.D2. April 2019
} 
terletak pada kenyataan ruhani, kepuasan hanya bisa dicapai dan dirasakan dengan memiliki nilai-nilai keruhanian yaitu idea. Dengan demikian, manusia yang terlahir ke dunia ini merupakan penjelmaan dari idea yang telah ada, dan telah mengetahui segala sesuatu dalam dunia ideanya.

Aliran materialisme merupakan aliran filsafat yang berisikan tentang ajaran kebendaan. Aliran ini berfikir sangat sederhana, bahwa segala sesuatu yang ada di alam ini dapat dilihat atau diobservasi, baik wujudnya, gerakannya maupun peristiwa-peristiwanya. Menurut aliran ini, gerakan manusia adalah bagian dari gerakan alam sehingga manusia tunduk dan terlibat dengan peristiwa hukum alam, hukum sebab-akibat (kausalitas), hukum obyektif. Reaksi manusia tersebut merupakan stimulus response. Thomas Hobbes sebagai salah satu tokoh aliran ini, menyatakan bahwa akal merupakan hasil perkembangan yang disebabkan adanya usaha manusia yang bukan pembawaan, melainkan ada oleh karena berinteraksi dengan alamnya. ${ }^{4}$

Aliran rasionalisme, tokoh aliran ini adalah Rene Descartes yang berpendapat bahwa sumber pengetahuan yang dapat dijadikan patokan dan dapat diuji kebenarannya adalah rasio. Namun, di sisi lain akal tidak dapat menemukan pengertian yang sempurna tanpa adanya keterkaitan dengan pengalaman. Maka pengalaman (eksperimen) bagi aliran ini merupakan perangsang bagi pikiran untuk menentukan kebenaran dan menganalisis suatu obyek. ${ }^{5}$ Setidaknya ketiga aliran tersebut diatas banyak mempengaruhi dalam pemikiran-pemikiran pendidikan.

Berdasarkan dari kajian pada sosok kompleks yang istimewa tersebut, para ahli filsafat memberikan berbagai predikat kepada manusia diantaranya: ${ }^{6}$ (a) Manusia adalah homo sapiens, artinya makhluk yang mempunyai budi pekerti, (b) Manusia adalah animal rational, artinya binatang yang dapat berpikir, (c) Manusia adalah bomo laquen, artinya makhluk yang pandai menciptakan bahasa, (d) Manusia adalah homo faber, artinya makhluk yang pandai membuat perkakas, (e) Manusia adalah zoon politicoi, artinya makhluk yang pandai bekerja sama, (f) Manusia adalah homo economicus, artinya makkhluk yang tunduk kepada prinsip-prinsip ekonomi, (g) Manusia adalah bomo religious, artinya makhluk yang beragama, (h) Manusia adalah bomo planemanet, artinya makhluk yang diantaranya terdiri unsur ruhaniah-spiritual, (h) Manusia

\footnotetext{
${ }^{4}$ Jalaluddin, Filsafat,.. 68

${ }^{5}$ Jalaluddin, Filsafat. 71

${ }^{6}$ Toto Suharto, Filsafat Pendidikan Islam (Jogjakarta: Ar-Ruzz, 2006), 92

Vol.미. No.D2. April 2민
} 


\section{Sulaiman}

adalah homo educandum, artinya makhluk yang dapat menerima pendidikan atau sering juga disebut dengan educable.

Dari beberapa predikat di atas menunjukkan bahwa manusia membutuhkan pendidikan dan mampu untuk melakukan pendidikan yang dimaksudkan bagi perkembangan manusia sendiri.

Dan selanjutnya dalam pandangan filsafat, setidaknya terdapat beberapa aliran besar yang mendasari perkembangan dalam dunia pendidikan menyangkut hal yang mempengaruhi dan menentukan perkembangan manusia. Diantara teori-teori tersebut antara lain: ${ }^{7}$

Pertama, Teori Empirisme disebut juga Paedagogi Optimisme atau tabula rasa, ${ }^{8}$ dipelopori oleh John Locke (1632-1704) yang menyatakan bahwa manusia lahir ke dunia ini dalam keadaan putih bersih bagaikan kertas kosong. Selanjutnya perkembangan seorang individu akan ditentukan oleh lingkungan atau pengalaman-pengalaman yang diperoleh individu selama menjalani kehidupannya. Bila disimpulkan, pendidikanlah yang akan membawa nasib manusia untuk ke depannya. Jika demikian yang terjadi, maka pelaksanaan pendidikan menjadi demikian urgen bagi manusia untuk mengisi kekosongan yang ada. Sehingga, tugas pendidik dalam proses berlangsungnya pendidikan adalah sebagai subyek aktif yang berperan penting memberikan pengetahuan dan pemahaman kepada peserta didik (yang bersifat pasif karena hanya sebagai penerima saja).

Kedua, Teori Nativisme (Schopenhauer, 1788-1880) disebut juga biologisme, paedagogik pesimisme, enfoldment atau faculty, ${ }^{9}$ menyebutkan bahwa dasar atau watak manusia diatur dan ditentukan oleh alam semesta pada saat lahir. Faktor-faktor nativus (pembawaan) lah yang mempengaruhi nasib dan perkembangan manusia, sehingga bagaimanapun kondisi lingkungan yang ada tidak menimbulkan efek yang berarti apa-apa bagi manusia. Singkatnya, dalam kehidupan manusia tidak dibutuhkan pengkondisian lingkungan untuk membentuk nasib manusia.

Ketiga, Teori Konvergensi, William Stearn (1871-1937) sebagai tokoh yang menyatakan ketidaksetujuannya terhadap pendapat empirisme dan nativisme yang demikian ekstrim, berpendapat bahwa perkembangan seorang individu tidak hanya ditentukan oleh nativis dan

\footnotetext{
${ }^{7}$ M. Jindar Wahyudi, Nalar Pendidikan Qur'ani (Yogyakarta: Apeiron Philotes, 2006), 18-20

${ }^{8}$ M. Suyudi, Pendidikan dalam Perspektif Al-Qur'an: Integrasi Epistimologi Bayani, Burhani dan Irfani, (Yogyakarta: Penerbit Mikraj, 2005), 38

${ }^{9}$ Suyudi, Pendidikan dalam Perspektif Al-Qur'an,.45

Jurnal Auladuna | 94

Vol.Dl. No.DZ. April 2019
} 
empiris saja melainkan dengan kedua faktor tersebut yang saling berkaitan (mempengaruhi). Teori ini merupakan jalan tengah yang memadukan kedua teori sebelumnya.

Dalam hal ini pandangan Islam lebih moderat dengan konsep fitrahnya, teori fitrah berbeda dengan teori nativisme, empirisme dan konvergen. Adapun inti pokok letak perbedaannya adalah teori fitrah lebih kompleks dan lengkap dalam membahas teori kejadian manusia. Manusia terlahir membawa fitrah yang dianugerahkan Allah, kemudian melalui proses pendidikan fitrah ditumbuh kembangkan menuju ke arah yang lebih baik. Nativisme mengatakan fitrah berasal dari alam sehingga takdir dapat ditentukan sendiri oleh setiap individu tertentu. Hal ini bertentangan dengan Islam yang sudah jelas bahwa takdir terbagi menjadi dua, yaitu takdir yang dapat dirubah dan takdir mutlak. Empirisme mengatakan bahwa pendidikan dan pengalaman-pengalaman hidup adalah faktor utama dalam perkembangan individu. Sedangkan konvergen merupakan gabungan dari nativisme dan empirisme. Sekilas teori fitrah lebih condong ke arah konvergen, namun perbedaannya terletak pada fitrah manusia yang berasal dari Allah SWT bukan dari alam.

\section{SETIAP INDIVIDU ADALAH PENDIDIK}

"Pendidik" sering disebut dengan murabbi, mu'allim, mu'addib, mudarris, dan mursyid. Kelima istilah ini mempunyai tempat tersendiri dan mempunyai tugas masing-masing sebagaimana dalam penjelasan berikut. ${ }^{10}$ Murabbi adalah orang yang mendidik dan menyiapkan peserta didik agar mampu berkreasi serta mampu mengatur dan memelihara hasil kreasinya untuk tidak menimbulkan malapetaka bagi dirinya, masyarakat dan alam sekitarnya. Mu'allim adalah orang yang menguasai ilmu dan mampu mengembangkannya sertamenjelaskan fungsinya dalam kehidupan, menjelaskan dimensi teoritis dan praktisnya, sekaligus melakukan transfer ilmu pengetahuan, internalisasi serta implementasi. Mu'addib adalah orang yang mampu menyiapkan peserta didik untuk bertanggungjawab dalam membangun peradaban yang berkualitas di masa depan. Mudarris adalah orang yang memiliki kepekaan intelektual dan informasi serta memperbaharui pengetahuan dan keahliannya secara berkelanjutan, dan berusaha mencerdaskan peserta didiknya, memberantas kebodohan mereka, serta melatih keterampilan sesuai dengan bakat, minat dan kemampuannya. Mursyid adalah orang yang

${ }^{10}$ www.tanbihun.com/pendidikan/pendidik-dalam-pendidikan-islam diakses 08 Oktober 2011

Vol.ㅁ. No.T2. April 2019

Jurnal Auladuna | 95 
mampu menjadi model atau sentral identifikasi diri atau menjadi pusat anutan, teladan dan konsultan bagi peserta didiknya.

Apapun istilah yang digunakan, pada dasarnya setiap manusia adalah pendidik, minimal bagi diri sendiri, anak dan keluarganya. Hal ini merupakan implikasi dari terciptanya manusia dengan kompleksitas yang tiada tara dibanding dengan makhluk lain yang ada.

Tugas mendidik yang melekat pada diri orang tua bukan saja karena hal itu merupakan perintah agama, melainkan juga karena mendidik anak merupakan bagian dari pemenuhan terhadap kebutuhan psikis (ruhani) dan kepentingan sebagai pribadi maupun sebagai anggota masyarakat. ${ }^{11}$ Pendidik dalam Islam adalah orang-orang yang bertanggung jawab terhadap perkembangan peserta didiknya dengan upaya mengembangkan seluruh potensi peserta didik, baik potensi afektif (rasa), kognitif (cipta), maupun psikomotorik (karsa). ${ }^{12}$

Pendidik berarti juga orang dewasa yang bertanggung jawab memberi pertolongan pada peserta didiknya dalam perkembangan jasmani dan rohaninya, agar mencapai tingkat kedewasaan, mampu berdiri sendiri dan memenuhi tingkat kedewasaannya, mampu mandiri dalam memenuhi tugasnya sebagai hamba dan khalifah Allah SWT. Dan mampu melaksanakan tugas sebagai makhluk social dan sebagai makhluk individu yang mandiri. ${ }^{13}$

Pendidik pertama dan utama adalah orangtua sendiri. Mereka berdua yang bertanggung jawab penuh atas kemajuan perkembangan anak kandungnya, karena sukses tidaknya anak sangat tergantung kepada pengasuhan, perhatian, dan pendidikannya. Kesuksesan anak kandung merupakan cermin atas kusuksesan orangtua juga. Firman Allah SWTT.

Artinya: " Hai orang-orang yang beriman, peliharalah dirimu dan keluargamu dari api neraka yang bahan bakarnya adalah manusia dan batu; penjaganya malaikat-malaikat yang kasar, keras, dan tidak mendurbakai Allah terhadap apa yang diperintabkan-Nya kepada mereka dan selalu mengerjakan apa yang diperintabkan. (Q.S At-tabrim:6) ${ }^{14}$

Pendidik disini adalah mereka yang memberikan pelajaran peserta didik, yang memegang suatu mata pelajaran tertentu di sekolah. ${ }^{15}$ Orangtua sebagai pendidik pertama dan utama terhadap anak-anaknya, tidak selamanya memiliki waktu yang leluasa dalam mendidik anak-anaknya. Selain karena kesibukan kerja, tingkat efektifitas dan efisiensi pendidikan tidak

${ }^{11}$ Moh. Roqib, Ilmu Pendidikan Islam: Pengembangan Pendidikan Intregatif di Sekolah, Keluarga dan Masyarakat (Yogyakarta: Lkis, 2009), 37

${ }^{12}$ Ahmad Tafsir, Ilmu Pendidikan dalam Perspektif Islam, (Bandung: Remaja Rosdakarya, 2002), 74-75

${ }^{13}$ Suryosubrata B., Beberapa Aspek Dasar Kependidikan, (Jakarta: Bina Aksara, 1983), 26

${ }^{14}$ Departemen Agama RI, 2005, al-qur'an dan terjemahan Bandung: Jumanatul Ali (Q.S At tahrim: 6)

${ }^{15}$ Ahmad Tafsir, Ilmu Pendidikan...75

Jurnal Auladuna | 96

Vol.DI. No.DZ. April 2019 
akan baik jika pendidikan hanya dikelola secara alamiah. Oleh karena itu, anak lazimnya dimasukkan ke dalam lembaga sekolah. Penyerahan peserta didik ke lembaga sekolah bukan berarti melepaskan tanggung jawab orangtua sebagai pendidik yang pertama dan utama, tetapi orangtua tetap mempunyai saham yang besar dalam membina dan mendidik anak kandungnya.

Dari penjelasan diatas, dapat dikatakan bahwa sebenarnya pada diri setiap individu manusia terdapat kewajiban untuk menjadi pendidik. Namun, dalam sebuah pendidikan yang terlaksana pada sebuah lembaga pendidikan tugas mendidik hanya bisa dilakukan oleh tenagatenaga yang berkompeten dengan beberapa persyaratan sebagai pendidik, seperti kompetensi paedagogik, kepribadian, sosial dan profesional. Karena peserta didik yang dihadapi merupakan individu yang kompleks dengan bermacam potensi yang perlu ditumbuh-kembangkan dengan kehati-hatian dan kecermatan.

Dalam hal ini, peran pendidik dalam proses pendidikan adalah sebagai pembimbing dan fasilitator. Pendidik sekedar membantu peserta didik untuk menggali segenap kemampuan fitrahnya yang merupakan bekal dasar dalam kehidupan, sehingga peserta didik mampu mengembangkan potensi positifnya dan mengeliminasi potensi negatifnya.

\section{KEDUDUKAN PENDIDIK DALAM PENDIDIKAN ISLAM}

Kedudukan pendidik dalam pendidikan Islam sangatlah penting dan terhormat, hal ini sebagaimana yang ditulis oleh Imam Al-Ghazali yang telah dikutib oleh Toto Suharto, Seseorang yang berilmu dan kemudian bekerja dengan ilmunya, dialah yang dinamakan orang besar di kolong langit ini. Dia itu ibarat matahari yang menyinari orang lain, dan menyinari dirinya sendiri. Ibarat minyak kasturi yang wanginya dapat dinikmati orang lain, dan ia sendiri pun harum. Siapa yang bekerja di bidang pendidikan, sesungguhnya ia telah memilih pekerjaan yang terhormat dan sangat penting. Maka hendaknya ia memelihara adab dan sopan santun dalam tugasnya ini". ${ }^{16}$

Orang yang mempunyai ilmu pengetahuan dalam Islam mendapatkan tempat yang dimuliakan karena Islam sangat menghormati yang demikian, Islam tidak dapat dikembangkan dan dilestarikan tanpa orang yang mempunyai ilmu. Hal ini dapat ditemukan dalam al-Qur'an surat al-Mujadalah ayat 11 di mana Allah sangat meninggikan orang yang beriman dan berilmu pengetahuan.

\footnotetext{
${ }^{16}$ Toto Suharto, Filsafat Pendidikan Islam (Jogjakarta: Ar-Ruzz, 2006), 119
} Vol.DI. No.D2. April 2019 
Sulaiman

Artinya:

Hai orang-orang beriman apabila kamu dikatakan kepadamu: "Berlapang-lapanglah dalam majlis", Maka lapangkanlah niscaya Allah akan memberi kelapangan untukmu. dan apabila dikatakan: "Berdirilah kamu", Maka berdirilah, niscaya Allab akan meninggikan orang-orang yang beriman di antaramu dan orang-orang yang diberi ilmu pengetahuan beberapa derajat. dan Allah Maha mengetahui apa yang kamu kerjakan. ${ }^{17}$

Orang yang berilmu atau 'alim merupakan realisasi ajaran Islam itu sendiri. ${ }^{18}$ Islam memuliakan pengetahuan, pengetahuan didapat dan diperoleh dari proses pembelajaran, yang belajar adalah calon guru dan yang mengajar adalah guru. Dalam konteks ini proses pembelajaran dalam kelas dapat terjadi adanya pendidik dan peserta didik, pendidik menyampaikan ilmu (transfer of knowledge), peserta menerima ilmu pengetahuan (given of knowledge) serta tanpa pendidik tidak bisa pembelajaran berjalan dan tanpa peserta didik pun pembelajaran mustahil dapat dilaksanakan.

Ahmad Tafsir lebih jauh menjelaskan umat Islam amat menghargai pendidik, disebabkan oleh pandangan bahwa ilmu pengetahuan itu semuanya bersumber pada Tuhan. Ilmu datang dari Tuhan, guru pertama adalah Tuhan. Pandangan yang menembus langit tidak boleh tidak telah melahirkan sikap pada orang Islam bahwa ilmu itu tidak terpisah dari Allah, ilmu tidak terpisah dari guru, maka kedudukan guru amat tinggi dalam Islam.

\section{PENUTUP}

Dari pemaparan diatas dapat disimpulkan bahwa hakikat manusia sebagai seorang pendidik kaitannya dalam pendidikan Islam adalah mendidik dan sekaligus di dalamnya mengajar sesuai dengan keilmuwan yang dimilikinya untuk membentuk pribadi muslim yang beriman dan bertakwa kepada Allah swt. pada umumnya pendidik adalah orang yang memiliki tanggung jawab untuk mendidik dengan mengajarkan ilmunya dalam rangka menciptakan dan mencetak generasi bangsa yang terdidik.

Keutamaan pendidik terletak pada tugas yang diembangnya yakni mendidik, mengajarkan sesuatu untuk diketahui oleh peserta didik. Demikian pula membentuk kepribadian yang berjiwa tauhid, kreatif, beramal salih dan bermoral tinggi, guna memperoleh keselamatan dunia dan akhirat.

\footnotetext{
${ }^{17}$ Departemen Agama RI, 2005, al-qur'an dan terjemahan Bandung: Jumanatul Ali (Q.S Al-Mujadalah: 11) ${ }^{18}$ Ahmad Tafsir, Ilmu Pendidikan dalam Perspektif Islam, (Bandung: Remaja Rosdakarya, 2002), 76 Jurnal Auladuna | 98

Vol.ㅁ. №.D2. April 2019
} 
Pada hakikat manusia sebagai pendidik dalam persepektif Islam adalah orang yang bertanggung jawab terhadap perkembangan peserta didik dengan upaya seluruh potensi peserta didik baik afektif, kognitif, maupun psikomotorik. Pendidik adalah bapak rohani (spiritual father) bagi anak didik yang memberikan santapan jiwa dengan ilmu, pembinaan akhlak mulia dan meluruskannya. Dengan demikian hal ini juga menunjukkan bahwa akhir pendidik merupakan profesi atau keahlian tertentu yang melekat pada diri seseorang yang tugasnya adalah untuk mendidik atau memberikan pendidikan. Oleh karena itu pendidik mempunyai kedudukan tinggi dihadapan sang kholiknya. Wallahu a'lam

\section{DAFTAR RUJUKAN}

Departemen Agama RI, 2005, al-qur'an dan terjemahan Bandung: Jumanatul Ali Jalaluddin dan Abdullah Idi. 2009. Filsafat Pendidikan. Yogjakarta: Ar-Ruzz Media M. Suyudi, 2005, Pendidikan dalam Perspektif Al-Qur'an: Integrasi Epistimologi Bayani, Burhani dan Irfani, Yogyakarta: Penerbit Mikraj

Roqib, Moh.. 2009. Ilmu Pendidikan Islam: Pengembangan Pendidikan Intregatif di Sekolah, Keluarga dan Masyarakat. Yogyakarta: LKis

Suharto, Toto. 2006. Filsafat Pendidikan Islam. Jogjakarta: Ar-Ruzz

Suryo Subrata B. 1983. Beberapa Aspek Dasar Kependidikan. Jakarta: Bina Aksara

Tafsir, Ahmad. 1992. Ilmu Pendidikan dalam Perspektif Islam. Bandung: Remaja Rosdakarya

www.tanbihun.com/pendidikan/pendidik-dalam-pendidikan-islam diakses 08 Oktober 2011

Vol.DI. No.QZ2. April 2019

Jurnal Auladuna 99 